\title{
Technical and Economic Research on Cast-in-place Concrete Hollow Floor Structure (City Building Engineering)
}

\author{
Lin Ronghui ${ }^{1}$, Lv Hui ${ }^{1}$, Lv Dae ${ }^{2}$ \\ 1 Jiangxi Institute of Economic Administrators, Nanchang 330088, China \\ 2 State Grid Jiangxi Economic Research Institute, Nanchang 330043, China
}

\begin{abstract}
Key words: hollow girderless floor structure, common beam-slab, economic benefit
Abstract. As a new type of construction technology, the hollow girderless floor structure has been widely used in many projects. The paper studied economic efficiency of the new hollow girderless floor structure system (with thin-walled bellows) and the common beam-slab structure system as the standard floor for city building projects. By comparison and analysis, it is concluded that the new hollow girderless floor structure technology would substantially cut construction material consumption and direct project cost and outperform the common beam-slab structure system. The longer the column span is and the larger the vertical load is, the more obvious the economic benefits are.
\end{abstract}

\section{Introduction to Cast-in-place Hollow Floor Structure}

A cast-in-place concrete hollow floor structure is one of the hollow floor structure technologies that arranges light materials at a certain order to replace the corresponding concrete in a solid floor structure and thus to form cavities which make a spatially compatible stress system with concealed rib beams. The technology of cast-in-place concrete hollow floor structure reduces the dead weight of the floor structure by $30 \% \sim 40 \%$ but maintains $80 \%$ 90\% structural rigidity of the floor structure. Moreover, its heat and sound insulation performances are both 2 times better than that of a normal floor structure. It is an important innovation in building structure in China which conforms to national strategic requirements for saving energy and reducing consumption in buildings. The technology is one of the new technologies that the central government promotes in civil buildings to save energy.

With social development, people require buildings develop towards large space, large span, large flat plate, high floor height, and flexible and various partition. To meet such requirements on building functions, structure forms change in several phases: traditional floor structure with primary and secondary beams $\longrightarrow$ one-way/two-way ribbed floor structure $\longrightarrow$ solid girderless plate $\longrightarrow$ pre-stress floor structure $\longrightarrow$ hollow floor structure. The cast-in-place concrete hollow floor structure once was listed among the key promotion projects by the Construction Ministry in 1999 and has been widely used in various projects, including multi-storey and high-rise public buildings, large-spaced shopping malls, teaching buildings, and underground garages. The cast-in-place concrete hollow floor structure has large advantages in both building functions and structure cost performance, as well as huge social economic values.

Thin-walled bellows are high-tech products with characteristics of light weight $(<4 \mathrm{~kg} / \mathrm{m})$, uniform material quality, multiple pipe diameters $(150 \mathrm{~mm} 450 \mathrm{~mm})$, easy construction, etc. Its wall won't be damaged during vibrating and ramming and it won't go upwards during casting. Such technology has integrated the advantages of various products and solved the problems of similar products, especially the repairability of concrete with cracks. It is irreplaceable among similar products. Rib of the bellow provide compression strength during concrete casting. In case of any crack of the concrete, the ribs extend under tension, while concrete in other places still holds on the bellow to limit the crack within a restricted area and to keep the integrity of the cavity for future repair. It puts forward a new solution to the problem that it's difficult to repair the crack in the hollow floor structure and thus it is a leading technology in the industry. 


\section{Technical Characteristics of Cast-in-place Hollow Floor Structure}

The cast-in-place hollow floor structure has more obvious social benefits and economic benefits in modern buildings that the common beam-slab structure system. Refer to Table 1 for a summary of optimized indexes:

Table 1. Technical characteristics of hollow floor structure

\begin{tabular}{|c|c|}
\hline $\begin{array}{c}\text { Characteristics of hollow floor } \\
\text { structure }\end{array}$ & Specific indexes \\
\hline 1. Reduce floor height & $\begin{array}{l}\text { It reduces beam height for } 0.4 \mathrm{~m} \sim 0.7 \text { per layer depending on } \\
\text { various spans. }\end{array}$ \\
\hline 2. Reduce concrete volume & $\begin{array}{l}\text { For buildings with a span more than } 5 \mathrm{~m} \text {, the concrete is } \\
\text { reduced by } 0.01-0.22 \mathrm{~m}^{3} / \mathrm{m}^{2} \text { for every square meter (which is } \\
\text { the largest compared with \#-shaped beam); }\end{array}$ \\
\hline 3. Reduce steel amount & $\begin{array}{l}\text { For floor slab whose span is more than } 5 \mathrm{~m} \text {, the steel amount is } \\
\text { reduced by } 5 \sim 20 \% \text { (in consideration of rebars in beams, slab, } \\
\text { and columns); }\end{array}$ \\
\hline 4. Reduce decoration cost & $\begin{array}{l}\text { The ceilings have no beam edges, which reduces the plastering } \\
\text { on the beam, improves indoor decoration effects, and saves } \\
2 \sim 6 \% \text {. }\end{array}$ \\
\hline 5. Reduce formwork input & $\begin{array}{l}\text { The formwork is reduced by } 0.3-1.2 \mathrm{~m}^{2} / \mathrm{m}^{2} \text { for every square } \\
\text { meter (which is the largest compared with 井 type beam); }\end{array}$ \\
\hline 6. Accelerate construction & $\begin{array}{l}\text { The formwork job is simple. All rebars are flat-paved. The } \\
\text { construction of each layer can be completed } 1 \sim 2 \text { days in } \\
\text { advance; }\end{array}$ \\
\hline 7. Reduce wall materials & $\begin{array}{l}\text { The internal walls are thinner for the user to install light walls. } \\
\text { The masonry is reduced by } 20 \sim 37 \% \text { in total; }\end{array}$ \\
\hline 8. Eliminate columns indoors & $\begin{array}{l}\text { The span is increased (from } 7.5 \mathrm{~m} \text { to } 8.4 \sim 9.0 \mathrm{~m} \text { ) and the number } \\
\text { of columns is reduced, which saves the cost greatly, i.e. by } \\
2 \sim 6 \% \text {; }\end{array}$ \\
\hline $\begin{array}{l}\text { 9. Reduce pipeline installation } \\
\text { cost }\end{array}$ & $\begin{array}{l}\text { The pipelines may be installed next to the ceiling, which } \\
\text { reduces bends and suspenders and thus reduces installation cost } \\
\text { by } 5 \sim 20 \% \text {; }\end{array}$ \\
\hline 10. Reduce labor & $\begin{array}{l}\text { All procedures of the floor slab become simple. The actual } \\
\text { labor is reduced relatively by } 2 \sim 12 \% \text {. }\end{array}$ \\
\hline 11. Save foundation cost & $\begin{array}{l}\text { The internal walls are thinner or the inside walls are } \\
\text { eliminated, and the floor slabs are lighter, so the load of the } \\
\text { foundation is reduced. Therefore, the cost is saved by } 2 \sim 4 \% \text {. }\end{array}$ \\
\hline 12. Save basement cost & $\begin{array}{l}\text { Less earthwork, non-deep foundation pit support, basement } \\
\text { height reduction by } 0.5 \sim 0.7 \mathrm{~m} \text { per every layer, reduced } \\
\text { thickness of vertical members and external enclosing vertical } \\
\text { members, low anti-floating water level, comprehensive cost } \\
\text { reduct by } 10 \sim 20 \% \text {. }\end{array}$ \\
\hline 13. Increase usable floor area & $\begin{array}{l}\text { The internal walls are thinner or the inside walls are } \\
\text { eliminated, so the usable floor area is increased by } \\
0.03-0.08 \mathrm{~m}^{2} / \mathrm{m}^{2} \text {; }\end{array}$ \\
\hline 14. Secondary upgrading & $\begin{array}{l}\text { The inside walls are not bearing walls, so the inside layout may } \\
\text { be upgraded at will at any time. It's of permanent value. }\end{array}$ \\
\hline
\end{tabular}




\begin{tabular}{l|l}
\hline $\begin{array}{c}\text { Characteristics of hollow floor } \\
\text { structure }\end{array}$ & \multicolumn{1}{c}{ Specific indexes } \\
\hline 15. Sound insulation & $\begin{array}{l}\text { The sound reduction index of hollow floor structure is } \\
25 \sim 40 \mathrm{~dB}, \text { which is much higher than that of ordinary floor } \\
\text { structure, 10 20dB; }\end{array}$ \\
\hline 16. Heat insulation & $\begin{array}{l}\text { The heat transmission coefficient } \mathrm{W} /(\mathrm{m} 2 \cdot \mathrm{K}) \text { of hollow floor } \\
\text { structure is 0.94-1.47, which is much lower than that of } \\
\text { ordinary floor structure (generally above 2.5); }\end{array}$ \\
\hline $\begin{array}{l}\text { 17. Room with large space and } \\
\text { good natural illumination }\end{array}$ & $\begin{array}{l}\text { The floor slab is of a large span but without beam under it, so } \\
\text { the room has the best inside environment and there is no shade } \\
\text { under the ceiling. }\end{array}$ \\
\hline
\end{tabular}

\section{Technical and Economic Analysis on Cast-in-place Concrete Hollow Floor Structure for City Building Engineering}

(i) Feasibility of Hollow Floor Structure Technology. Multi-storey and high-rise public buildings require large space and flexible partition to bring good quality experience to clients. The hollow floor structure technology is able to reduce structural member height and floor height to increase inside clearance; reduce beam side formwork and plastering to create an open and bright space; reduce noise between layers and intensify moisture preservation and heat insulation; and be partitioned at will for a more flexible space, so it has obvious advantage in functions. The technology of hollow girderless floor structure with thin-walled hollows is able to both optimize building functions and save cost estimate at the same time.

Figure 1. 3D effect diagram for traditional girder floor structure

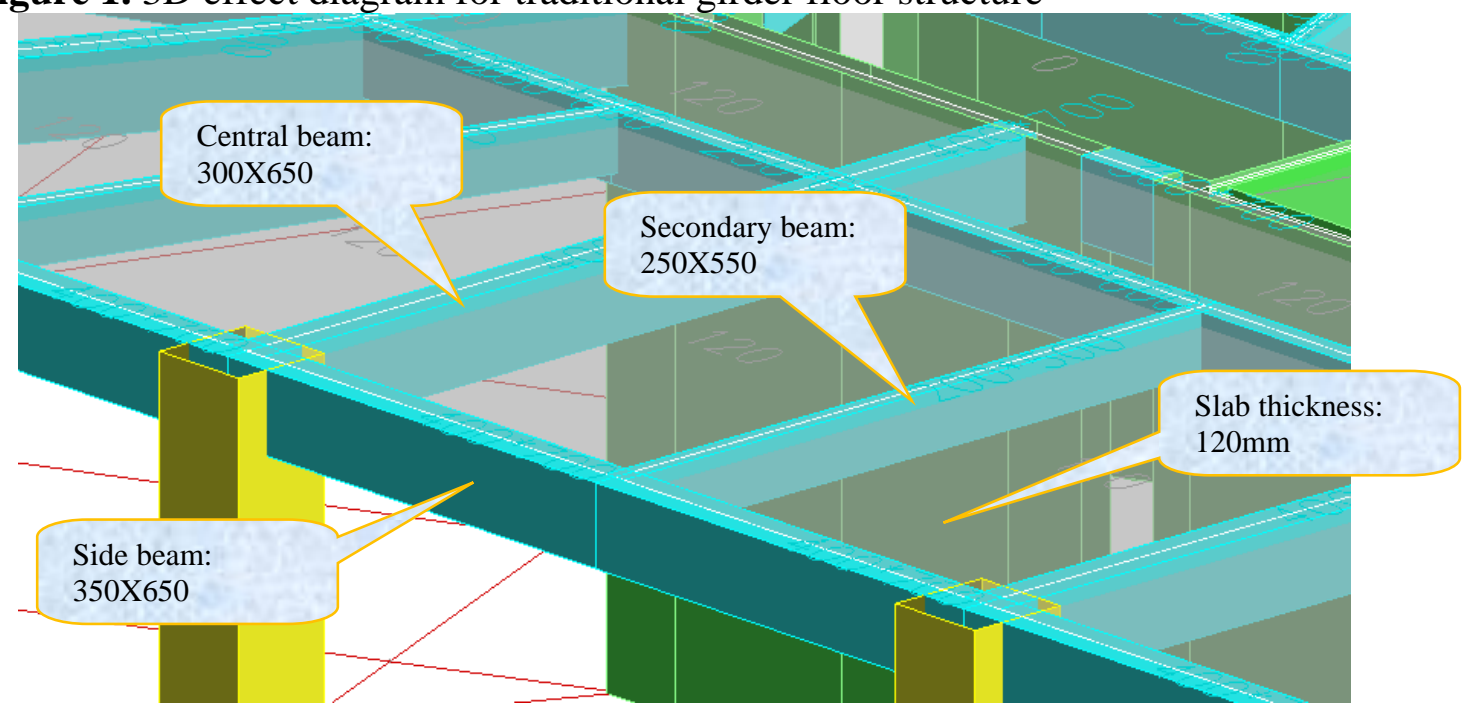

Figure 2. Local effect diagram for traditional girder floor structure 


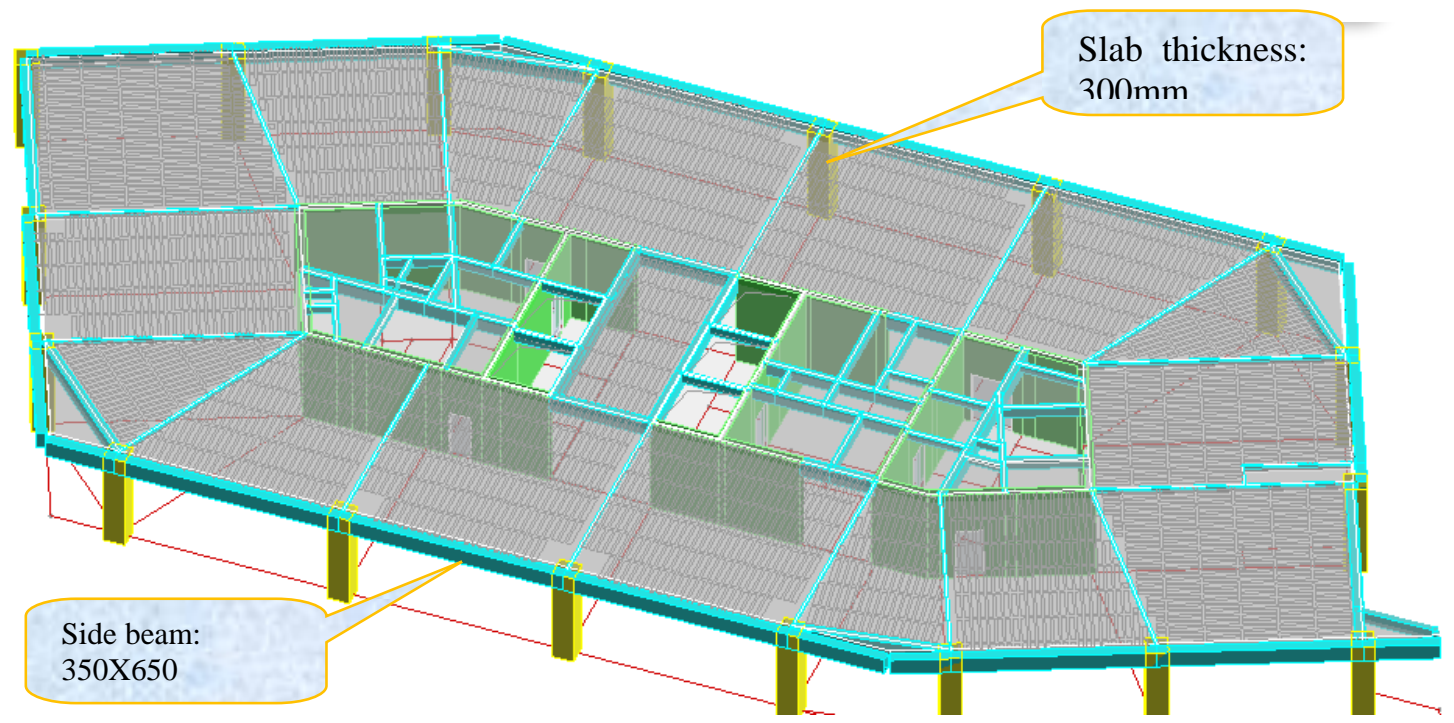

Figure 3. 3D effect diagram for hollow floor structure

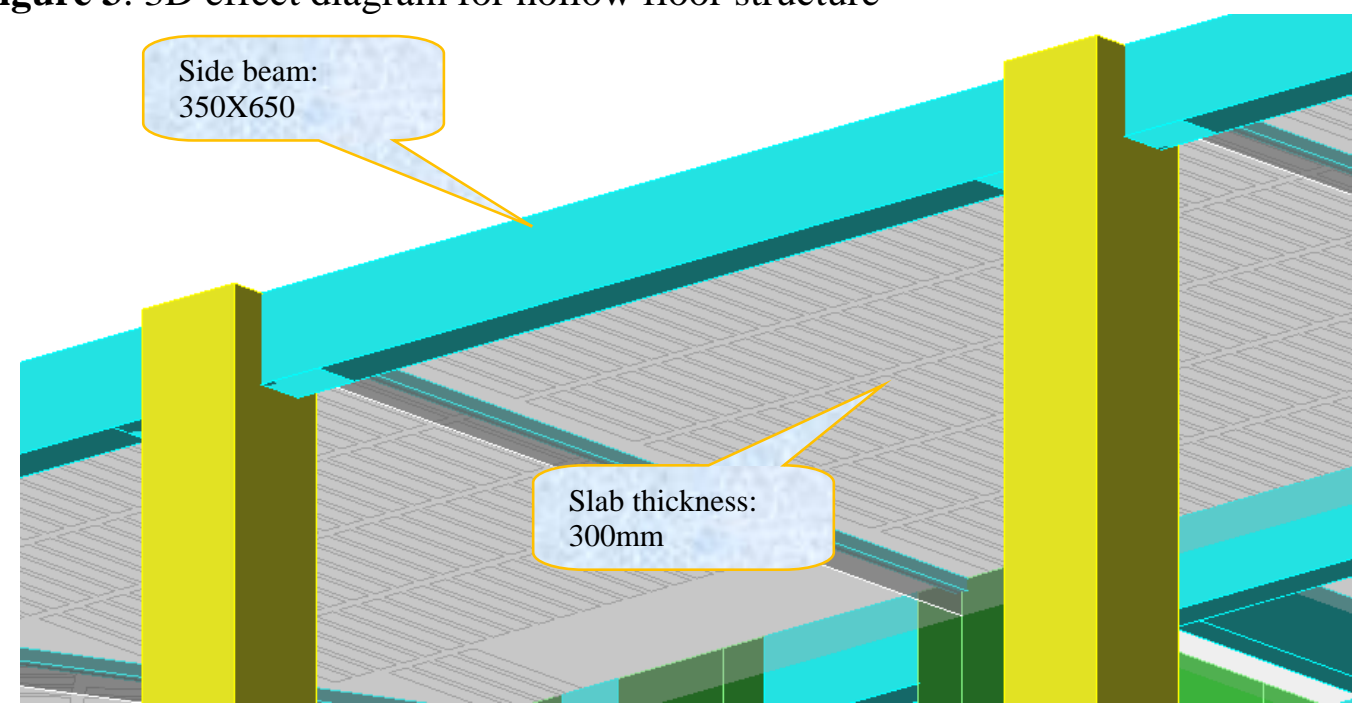

Figure 4. Local effect diagram for hollow floor structure

Refer to Table 2 for comparison results of economic efficiency of the two structure options.

Table 2. Indexes of hollow floor structure and ordinary girder floor structure

\begin{tabular}{|c|c|c|c|c|}
\hline \multicolumn{3}{|c|}{ Standard layer of city buildings } & Floor area $\mathrm{m}^{2}$ & 1201 \\
\hline & \multicolumn{2}{|c|}{$\begin{array}{l}\text { Indexes of ordinary girder floor } \\
\text { structure }\end{array}$} & \multicolumn{2}{|c|}{ Hollow floor structure } \\
\hline \multirow{2}{*}{ Beam-slab rebar } & Index $\mathrm{kg} / \mathrm{m}^{2}$ & 27.2 & Index $\mathrm{kg} / \mathrm{m}^{2}$ & 26.4 \\
\hline & Quantities kg & 32667 & Quantities kg & 31706 \\
\hline \multirow{2}{*}{ Beam-slab concrete } & Index $\mathrm{m}^{3} / \mathrm{m}^{2}$ & 0.228 & Index $\mathrm{m}^{3} / \mathrm{m}^{2}$ & 0.218 \\
\hline & Quantities $\mathrm{m}^{3}$ & 273 & Quantities $\mathrm{m}^{3}$ & 261.8 \\
\hline \multirow{2}{*}{$\begin{array}{l}\text { Beam-slab } \\
\text { scaffolding } \\
\text { formwork }\end{array}$} & Index $\mathrm{m}^{2} / \mathrm{m}^{2}$ & 1.7 & Index $\mathrm{m}^{2} / \mathrm{m}^{2}$ & 1.02 \\
\hline & Quantities m2 & 2041.7 & Quantities m2 & 1225 \\
\hline Ceiling decoration & Index $\mathrm{m}^{2} / \mathrm{m}^{2}$ & 1.7 & Index $\mathrm{m}^{2} / \mathrm{m}^{2}$ & 1 \\
\hline
\end{tabular}




\begin{tabular}{|c|c|c|c|c|}
\hline & Quantities $\mathrm{m}^{2}$ & 2041.7 & Quantities $\mathrm{m}^{2}$ & 1225 \\
\hline \multirow{2}{*}{ Core formwork } & Index $\mathrm{m} / \mathrm{m}^{2}$ & - & Index $\mathrm{m} / \mathrm{m}^{2}$ & 1 \\
\hline & Quantities $\mathrm{m}^{2}$ & - & Quantities $\mathrm{m}^{2}$ & 1201 \\
\hline \multirow{3}{*}{ Total \& comparison } & Cost $(\mathrm{CNY})$ & 506702 & Cost $(\mathrm{CNY})$ & 456380 \\
\hline & $\begin{array}{l}\text { Unit cost } \\
\left(\mathrm{CNY} / \mathrm{m}^{2}\right)\end{array}$ & 421.9 & $\begin{array}{l}\text { Unit cost } \\
\left(\mathrm{CNY} / \mathrm{m}^{2}\right)\end{array}$ & 390.5 \\
\hline & \multicolumn{3}{|c|}{$\begin{array}{l}\text { Cost saving rate of hollow girderless floor structure } \\
\text { compared with girder floor structure }\end{array}$} & $9.93 \%$ \\
\hline Man-days & \multicolumn{3}{|c|}{$\begin{array}{l}\text { Labor cost saving rate of hollow floor structure } \\
\text { compared with ordinary girder floor structure }\end{array}$} & $12 \%$ \\
\hline Construction schedule & \multicolumn{3}{|c|}{ Improved (3 5 days less for every layer) } & $20 \%$ \\
\hline Reduced floor height & \multicolumn{3}{|c|}{$\begin{array}{l}\text { Floor height reduced by about } 40 \mathrm{~cm} \text { for every layer. } \\
\text { The floor height could be considered to be reduced. } \\
\text { The comprehensive cost is saved by about } 1.5 \% \text { for } \\
\text { every } 10 \mathrm{~cm} \text { reduction of floor height. }\end{array}$} & $6.0 \%$ \\
\hline $\begin{array}{l}\text { Equipment installation } \\
\text { cost }\end{array}$ & \multicolumn{3}{|c|}{$\begin{array}{l}2 / 3 \text { smoke detectors ( } 400 \mathrm{CNY} / \text { detector) are reduced } \\
\text { and } 1 / 4 \text { sprayers are reduced, so the cost is saved. }\end{array}$} & 15 \\
\hline \multirow[t]{2}{*}{$\begin{array}{l}\text { Comprehensive } \\
\text { comparison }\end{array}$} & Unit cost & 421.9 & Unit cost & 383.9 \\
\hline & $\begin{array}{l}\text { Ordinary girder } \\
\text { floor structure }\end{array}$ & $\left(\mathrm{CNY} / \mathrm{m}^{2}\right)$ & $\begin{array}{l}\text { Hollow } \\
\text { girderless } \\
\text { floor } \\
\text { structural }\end{array}$ & $\left(\mathrm{CNY} / \mathrm{m}^{2}\right)$ \\
\hline
\end{tabular}

Note: 1. Rebar price: $3000 \mathrm{CNY/t}$; Labor cost: $1000 \mathrm{CNY} / \mathrm{t}$; Concrete: $400 \mathrm{CNY} / \mathrm{t}$; Scaffolding formwork: 70-150 CNY/m2; Plastering: 25-40 CNY/m2; Core formwork: $126 \mathrm{CNY} / \mathrm{m}^{2}$.

\section{Conclusions and Recommendations of Economic Analysis}

The following conclusions are drawn from the results of economic analysis comparison of floor structure systems as standard layer of city buildings and market survey.

1) Alleviate labor shortage problem. The formwork setting of ordinary concrete girder structure differs greatly from that of hollow floor structure. The hollow floor structure requires only flat formwork, which saves side formwork, reduces formwork loss, so the number of man-days is reduced greatly and the labor shortage problem is alleviated.

2) From the viewpoint of functions, the hollow floor structure is without girder for space division, so the structure is simple and light and improves visual effects of the building. The space is more flexible due to division at will. It has obvious advantage in functions and convenience in pipeline and pipe equipment installation, which saves pipe installation cost and reduces the total cost.

3) The hollow floor structure technology is a green building technology which is able not only to reduce concrete amount and save energy during construction but also to save more energy when the building is put into use.

In consideration of the comprehensive benefits from the above items, the option of hollow floor structure is of obvious advantages in functions and in cost compared with the option of ordinary concrete floor structure with primary and secondary beams. 


\section{References}

[1] Bai Liuyang. Brief Talk on Application of Cast-in-situ concrete hollow slab in the Underground Garages [J]. Engineering and Architectural Design, 2015;

[2] Wang Chunpei, Luo Zhaohui, Feng Chengcheng. Analysis of Influence of Position of Opening on Mechanical Property of Concrete hollow slab [J]. Journal of Tianjin Urban Construction Institute, 2015, 21 (1): 31-35.

[3] Lin Jie. Plate Conversion Layer Cast-in-situ concrete hollow slab Construction Technology and Quality Control[J]. Private Science and Technology, 2014 (4):208-208;

[4] Han Jun. Experimental Study and Finite Element Analysis on hollow slab Under Vertical Load [D]. Zhejiang University, 2015;

Fund program: Science and technology research (key) funded project of the Education Department of Jiangxi, No.: (Grant No.GJJ151585) 